\title{
Boron nitride supported PtFe catalysts for selective hydrogenation of crotonaldehyde
}

\author{
Jeffrey C.S. Wu*, Tai-Shin Cheng, Chao-Ling Lai \\ Department of Chemical Engineering, National Taiwan University, Taipei 10617, ROC \\ Received 18 May 2006; received in revised form 1 August 2006; accepted 16 August 2006 \\ Available online 20 September 2006
}

\begin{abstract}
The selective hydrogenation of crotonaldehyde was studied using boron nitride (BN) supported PtFe catalyst. A higher selectivity of crotyl alcohol than butyraldehyde was obtained, although butyraldehyde is thermodynamic favorable in the hydrogenation. The catalyst, PtFe/BN, was prepared by co-incipient wetness method. The metal loadings were $1.1 \mathrm{wt}$ \% Pt and Fe ranging 0.1-0.6 wt.\%. Commercial catalyst supports, graphite and $\gamma-\mathrm{Al}_{2} \mathrm{O}_{3}$, were also used to compare with $\mathrm{BN}$. The higher iron content, the higher the crotyl alcohol selectivity was, while the activity was depressed. $\mathrm{PtFe} / \gamma-\mathrm{Al}_{2} \mathrm{O}_{3}$ gave the lowest selectivity of crotyl alcohol. PtFe/graphite had the product selectivities similar to PtFe/BN, but its activity was lower than that of $\mathrm{PtFe} / \mathrm{BN}$. A maximum yield of crotyl alcohol was found at $0.2 \mathrm{wt} . \% \mathrm{Fe}(\mathrm{molar}$ ratio $\mathrm{Fe} / \mathrm{Pt}=0.64)$ on $\mathrm{PtFe} / \mathrm{BN}$ catalysts at $100{ }^{\circ} \mathrm{C}$. XRD revealed that $\mathrm{PtFe}$ alloy was formed on $\mathrm{PtFe} / \mathrm{BN}$ during $\mathrm{H}_{2}$ reduction at $300{ }^{\circ} \mathrm{C}$. The improvement of selectivity toward crotyl alcohol was attributed to the easier formation of PtFe alloy particle on $\mathrm{BN}$ surface than on $\gamma-\mathrm{Al}_{2} \mathrm{O}_{3}$. The Fe $\mathrm{Fe}^{2+}$ on $\mathrm{PtFe}$ alloy polarizes the $\mathrm{C}=\mathrm{O}$ bond of crotonaldehyde and the nearby $\mathrm{Pt}^{\circ}$ supplies the absorbed hydrogen to conduct the hydrogenation of the $\mathrm{C}=\mathrm{O}$ bond, instead of the $\mathrm{C}=\mathrm{C}$ bond. Therefore, both activity and the selectivity toward crotyl alcohol were enhanced appreciably.

(C) 2006 Elsevier B.V. All rights reserved.
\end{abstract}

Keywords: PtFe catalyst; Boron nitride; Selective hydrogenation; Crotonaldehyde

\section{Introduction}

The selective hydrogenation of an $\alpha, \beta$-unsaturated aldehyde into an unsaturated alcohol is an important process in the pharmaceutical, fine chemicals, and fragrance industries [1]. However, the hydrogenation of the $\mathrm{C}=\mathrm{C}$ bond is thermodynamically favorable over the $\mathrm{C}=\mathrm{O}$ bond, which leads to the undesirable product, saturated aldehydes. Based on Gibbs free energy calculation, butyraldehyde is favorable product of crotonaldehyde hydrogenation. Eqs. (1) and (2) show the Gibbs free energies and equilibrium constants of butyraldehyde and crotyl alcohol from crotonaldehyde hydrogenation at $298 \mathrm{~K}$, respectively [2]. The equilibrium constant of butyraldehyde is eleven order of magnitudes higher than that of crotyl alcohol. Improved selectivity for unsaturated alcohols was achieved by using reducible supports or additive promoter [3-6]. Supported bimetallic PtFe catalyst was also suggested to be an effective catalyst for the selective hydrogenation of $\alpha, \beta$-unsaturated

\footnotetext{
* Corresponding author. Tel.: +886 223631 994; fax: +886 223623040 . E-mail address: cswu@ntu.edu.tw (J.C.S. Wu).
}

aldehyde into an unsaturated alcohol, such as crotonaldehyde to crotyl alcohol $[7,8]$.

$$
\begin{gathered}
\mathrm{CH}_{3} \mathrm{CH}=\mathrm{CHCHO}+\mathrm{H}_{2} \stackrel{K_{1}}{\longrightarrow} \mathrm{CH}_{3} \mathrm{CH}_{2} \mathrm{CH}_{2} \mathrm{CHO} \\
G_{1}=-138.6 \mathrm{kj} / \mathrm{mol}, K_{1}=2.0 \times 10^{24} \\
\mathrm{CH}_{3} \mathrm{CH}=\mathrm{CHCHO}+\mathrm{H}_{2} \stackrel{K_{2}}{\longleftrightarrow} \mathrm{CH}_{3} \mathrm{CH}=\mathrm{CHCH}_{2} \mathrm{OH} \\
G_{2}=-77.3 \mathrm{kj} / \mathrm{mol}, K_{2}=3.6 \times 10^{13}
\end{gathered}
$$

Materials traditionally used as supports are insulating oxides such as $\mathrm{SiO}_{2}, \gamma-\mathrm{Al}_{2} \mathrm{O}_{3}$, silica-alumina, and various zeolites. These oxides possess large surface area, numerous acidic/basic sites, and metal-support interaction that offer particular catalytic activity for many reactions. Metal oxides have also been thoroughly studied and employed in the chemical industry for decades. On the other hand, non-oxide materials hold many unique properties unlike metal oxides, such as high thermal conductivity, acid-base resistance and possibly negligible metalsupport interaction. Such catalytic properties are worth to explore. Boron nitride $(\mathrm{BN})$ has been used as catalyst support 
recently $[9,10]$. The graphite-like hexagonal $\mathrm{BN}$ is the most stable BN isomer under ambient conditions [11]. In general, BN is inert material for catalytic reaction. In a supported metal system such as $\mathrm{Pt} / \mathrm{BN}, \mathrm{BN}$ has been shown to have a negligible interaction with $\mathrm{Pt}$ in the catalytic oxidation [9]. The easy migration of Pt particles occurred on the crystalline face of $\mathrm{BN}$ due to the weaker bonding between the crystalline face and $\mathrm{Pt}$ $[9,10]$. Such effect may promote the metal sintering and lead to the formation of bimetallic alloy, a favorable active site for the selective hydrogenation of $\alpha, \beta$-unsaturated aldehyde into unsaturated alcohol $[7,8]$. We therefore chose crotonaldehyde hydrogenation to investigate the unique catalytic property provided by a novel BN support. Our previous study indicated that PtSn alloy on $\mathrm{BN}$ support significantly enhanced the selectivity toward crotyl alcohol in crotonaldehyde hydrogenation [12]. In this study, the Fe addition on the surface characteristics and properties of Pt were explored in relation to the activity/selectivity of crotonaldehyde hydrogenation in vapor phase. The influence of different supports and the ratio of $\mathrm{H}_{2}$ /crotonaldehyde on product selectivity were also studied.

\section{Experimental}

\subsection{Catalyst preparation}

Hexagonal-BN was obtained from High Performance Materials Inc. (Taiwan). It was crystallized at roughly $800{ }^{\circ} \mathrm{C}$ during synthesis, a temperature lower than the typical $1000{ }^{\circ} \mathrm{C}$. Gamma alumina $\left(\gamma-\mathrm{Al}_{2} \mathrm{O}_{3}\right)$ from Merck (USA) and graphite (G) from Hon-Ming Tech (Taiwan) were used as supports for comparison. Precursor salt, $\mathrm{H}_{2} \mathrm{PtCl}_{6} \cdot 6 \mathrm{H}_{2} \mathrm{O}$ (Alfa Aesar), contains approximately $40 \mathrm{wt} \%$ platinum. Reagent grade $\mathrm{Fe}\left(\mathrm{NO}_{3}\right)_{3} \cdot 9 \mathrm{H}_{2} \mathrm{O}$ were purchased from Riedel-de Haen. Methanol (Fluka) was chosen as the diluting solvent for improved soaking of the hydrophobic BN and graphite supports. The supported PtFe catalysts were prepared utilizing a co-incipient wetness method. The quantity of methanol required to completely fill the support's pore volume was predetermined. Calculated amounts of $\mathrm{Pt}$ and $\mathrm{Fe}$ precursor salts were dissolved together in methanol to obtain the desired metal loadings. After the co-incipient wetness process was applied, catalysts were air-dried at room temperature for $24 \mathrm{~h}$; these are referred to as fresh catalysts. The detailed incipient wetness procedure can be found in the literature [13]. Pt loading was fixed at $1.1 \mathrm{wt} . \%$; Fe loadings varied from 0.1 to $0.6 \mathrm{wt} . \%$. The X.X wt.\% of Fe loading was assigned as Pt1.1FeX.X/BN (or $\mathrm{G}, \gamma-\mathrm{Al}_{2} \mathrm{O}_{3}$ ). In addition, monometallic $1.1 \mathrm{wt} . \% \mathrm{Pt}$ and $0.8 \mathrm{wt} . \%$ Fe catalysts were also prepared for comparison. In some catalysts, both Pt and Fe loadings proportionally increased four times in order to obtain enough signal strength in characterization. The catalytic hydrogenation was also tested on these catalysts. The product selectivities were found to be the same as those with normal metal loadings.

\subsection{Characterization}

The specific surface area of the support was measured by $\mathrm{N}_{2}$ adsorption in Micromeritics ASAP 2010. The particle sizes and distributions of $\mathrm{BN}$, graphite and $\mathrm{Al}_{2} \mathrm{O}_{3}$ were measured by laser-light scattering. $\mathrm{Al}_{2} \mathrm{O}_{3}$ was suspended and dispersed ultrasonically in water for $3 \mathrm{~min}$. $\mathrm{BN}$ or graphite was dispersed in ethanol due to its hydrophobicity. Coulter LS 230 was used to measured the scattering of incidental light at the $90^{\circ}$ position, then the particle size was calculated using the Fraunhofer equation. Fresh catalyst was reduced in $\mathrm{H}_{2}$ flow at $300{ }^{\circ} \mathrm{C}$ for $2 \mathrm{~h}$ before chemisorption. The $\mathrm{H}_{2}$ chemisorption procedures were similar to those described by Yang and Goodwin [14]. The amount of irreversible $\mathrm{H}_{2}$ chemisorption was taken to determine the Pt dispersion. A transmission electron microscope (TEM, Hitachi H-7100) was employed to observe the shape of $\mathrm{BN}$ and the appearance of PtFe particles dispersed on the support. The crystalline phases of catalysts were identified by X-ray diffraction (XRD). The XRD equipment, type M03XHF22 from the Material Analysis and Characterization Company, was operated at $40 \mathrm{kV}$, with a $1.54056 \AA \mathrm{X}$-ray wavelength from a $\mathrm{Cu}$ target, and a scanning speed of $0.5 \% \mathrm{~min}$. $\mathrm{X}$-ray photoelectron spectroscopy (XPS) was conducted on a spectrometer of VG Microtech MT500. The measured binding energy was referenced to carbon (1s) at $285.6 \mathrm{eV}$. The reduction of fresh PtFe catalyst was studied using the temperature programmed reduction (TPR). The gas used in TPR was a mixture of 5 vol. $\% \mathrm{H}_{2}$ in Ar. A fresh catalyst was loaded into a quartz tube and purged with $\mathrm{N}_{2}$. The gas was then switched to the $\mathrm{H}_{2} / \mathrm{Ar}$ mixture at room temperature. The TPR was performed in the $\mathrm{H}_{2} / \mathrm{Ar}$ mixture from 30 to $600{ }^{\circ} \mathrm{C}$ at a constant heating rate of $10{ }^{\circ} \mathrm{C} / \mathrm{min}$.

\subsection{Catalytic reaction}

Fresh catalyst $(0.3 \mathrm{~g})$ was charged in the middle of a straighttube quartz reactor with a 10-mm I.D. The catalyst was reduced for $2 \mathrm{~h}$ at $300{ }^{\circ} \mathrm{C}$, using pure hydrogen $(99.999 \%)$ in the reactor and then cooled to $40{ }^{\circ} \mathrm{C}$ before switching to the reactant mixture. The reactant mixture was composed by flowing pure hydrogen into a saturator filled with liquid crotonaldehyde. Crotonaldehyde (98\%) was purchased from Fluka. The concentration of crotonaldehyde in the reactant mixture was adjusted by tuning the saturator temperature, and the concentration was further confirmed by an on-line GC before reaction. The molar ratio of $\mathrm{H}_{2}$ /crotonaldehyde mixture varied from 30 to 90 and passed through the reactor at $50 \mathrm{ml} / \mathrm{min}$ under atmospheric pressure. The reaction temperature was increased from 40 to $120{ }^{\circ} \mathrm{C}$ in a tubular furnace. A thermocouple was placed in the center of the catalyst bed to record the reaction temperature and to control the furnace. All gas lines were wrapped in heating tape and kept warm to prevent condensation. The products of crotonaldehyde hydrogenation were measured by an on-line GC (HP GC6890) equipped with a $30 \mathrm{~m}$ HP-Innowax capillary column using a flame ionization detector. The activities of PtFe catalyst were measured after achieving steady-state at $40{ }^{\circ} \mathrm{C}$. It took about $30 \mathrm{~min}$ to obtain steady-state conversion. The reaction temperature was then raised to $60{ }^{\circ} \mathrm{C}, 80{ }^{\circ} \mathrm{C}, 100{ }^{\circ} \mathrm{C}$ and $120{ }^{\circ} \mathrm{C}$ to investigate the variations of conversion and product selectivity. The same hydrogenation reaction conducted on $\mathrm{Fe} /$ 
Table 1

Hydrogen chemisorption of BN supported metal catalysts

\begin{tabular}{lllcl}
\hline Catalyst & $\mathrm{Fe}(w \mathrm{wt} \%)$ & $\mathrm{Fe} / \mathrm{Pt}(\mathrm{at})$ & $\mathrm{H}_{2}(\mu \mathrm{mol} / \mathrm{g}$-cat $)$ & $\mathrm{H} / \mathrm{Pt}$ \\
\hline $\mathrm{Pt} 1.1 / \mathrm{BN}$ & 0 & 0.00 & 7.93 & 0.28 \\
$\mathrm{Pt} 1.1 \mathrm{Fe} 0.1 / \mathrm{BN}$ & 0.1 & 0.32 & 6.15 & 0.22 \\
$\mathrm{Pt} 1.1 \mathrm{Fe} 0.2 / \mathrm{BN}$ & 0.2 & 0.64 & 5.53 & 0.20 \\
$\mathrm{Pt} 1.1 \mathrm{Fe} 0.4 / \mathrm{BN}$ & 0.4 & 1.27 & 4.13 & 0.15 \\
$\mathrm{Pt} 1.1 \mathrm{Fe} 0.6 / \mathrm{BN}$ & 0.6 & 1.91 & 0.60 & 0.02 \\
$\mathrm{Pt} 1.1 / \mathrm{G}$ & $\mathrm{a}$ & 0.00 & 15.04 & 0.53 \\
$\mathrm{Pt} 1.1 \mathrm{Fe} 0.2 / \mathrm{G}$ & 0.2 & 0.64 & 11.82 & 0.42 \\
$\mathrm{Pt} 1.1 \mathrm{Fe} 0.4 / \mathrm{G}$ & 0.4 & 1.27 & 6.76 & 0.24 \\
$\mathrm{Pt} 1.1 \mathrm{Fe} 0.6 / \mathrm{G}$ & 0.6 & 1.91 & 4.04 & 0.14 \\
$\mathrm{Pt} 1.1 / \gamma-\mathrm{Al}{ }_{2} \mathrm{O}_{3}$ & 0 & 0.00 & 36.06 & 1.28 \\
$\mathrm{Pt} 1.1 \mathrm{Fe} 0.2 / \gamma-\mathrm{Al}_{2} \mathrm{O}_{3}$ & 0.2 & 0.64 & 6.01 & 0.21 \\
$\mathrm{Pt} 1.1 \mathrm{Fe} 0.4 / \gamma-\mathrm{Al}_{2} \mathrm{O}_{3}$ & 0.4 & 1.27 & 4.84 & 0.17 \\
$\mathrm{Pt} 1.1 \mathrm{Fe} 0.6 / \gamma-\mathrm{Al}_{2} \mathrm{O}_{3}$ & 0.6 & 1.91 & 4.29 & 0.15 \\
\hline $\mathrm{Ct}$ & 0.6 & &
\end{tabular}

Catalysts $\mathrm{H}_{2}$ reduced at $300{ }^{\circ} \mathrm{C}$ for $2 \mathrm{~h}$ before chemisorption.

${ }^{\text {a }} \mathrm{G}$ : graphite.

BN catalyst and BN support found no activity up to $100{ }^{\circ} \mathrm{C}$. The conversion of crotonaldehyde and the selectivity of product were calculated using Eqs. (3) and (4). The yield of crotyl alcohol was calculated by multiplying the conversion by its selectivity.

$$
\begin{aligned}
& \text { Conversion }(\%) \\
& =\frac{C_{\text {crotonaldehyde }} \text { Input }-C_{\text {crotonaldehyde Output }}}{C_{\text {crotonaldehyde }} \text { Input }} \times 100 \%
\end{aligned}
$$

Selectivity $=\frac{C_{\text {product }}}{C_{\text {crotonaldehyde }} \text { Input }-C_{\text {crotonaldehyde }} \text { Output }}$

\section{Results}

The specific surface areas of $\mathrm{BN}$, graphite and $\gamma-\mathrm{Al}_{2} \mathrm{O}_{3}$ are $46.3,7.8$ and $114.9 \mathrm{~m}^{2} / \mathrm{g}$, respectively. The mean particle size of $\mathrm{BN}$, graphite and $\gamma-\mathrm{Al}_{2} \mathrm{O}_{3}$ are calculated to be 2.8, 11 and $66.4 \mu \mathrm{m}$, respectively, from the results of the laser-light scattering. Table 1 summarizes the results of $\mathrm{H}_{2}$ chemisorption on all catalysts. Various $\mathrm{H}_{2}$ chemisorptions of monometallic $\mathrm{Pt}$ on $\mathrm{BN}$, graphite and $\gamma-\mathrm{Al}_{2} \mathrm{O}_{3}$ indicate the different $\mathrm{Pt}$ dispersions, which are due to the nature of supports. The lowest $\mathrm{Pt}$ dispersion on $\mathrm{BN}$ is because the easy migration of $\mathrm{Pt}$ creates large particle on $\mathrm{BN}$ surface during $\mathrm{H}_{2}$ reduction. For all catalysts, the higher the $\mathrm{Fe}$ loading, the lesser the $\mathrm{H}_{2}$ chemisorption. The amounts of $\mathrm{H}_{2}$ chemisorption on $\mathrm{PtFe}$ catalysts decrease due to the Fe dilution or coverage of the surface $\mathrm{Pt}$ in these catalysts. The support, $\gamma-\mathrm{Al}_{2} \mathrm{O}_{3}$, shows the ratio of $\mathrm{H} / \mathrm{Pt}>1$ may be caused by $\mathrm{H}_{2}$ spillover.

\subsection{Hydrogenation of crotonaldehyde}

Fig. 1 depicts the reaction paths of $\alpha, \beta$ hydrogenation on crotonaldehyde. The product is either crotyl alcohol or butyraldehyde via $\mathrm{C}=\mathrm{O}$ or $\mathrm{C}=\mathrm{C}$ hydrogenation. Butyraldehyde is thermodynamically favorable in crotonaldehyde hydrogenation based on Gibbs free energy calculation. The final product is butanol with further hydrogenation of either crotyl alcohol or butyraldehyde.

Fig. 2 shows the effect of Fe loadings on the selectivity of crotyl alcohol and the yields of products on BN supported catalysts at $100{ }^{\circ} \mathrm{C}$. The yields of crotyl alcohol, butanol and butyraldehyde increase because the conversions increase with $\mathrm{Fe}$ adding on the catalysts. When Fe loadings increase from 0.1 to 0.6 wt. $\%$, the yields of butyraldehyde and butanol decrease significantly. The selectivity of crotyl alcohol consistently increases with Fe loading is due to the suppression of butyraldehyde and butanol. Such trends are similar in other temperatures (i.e. 40, 60, 80 and $120{ }^{\circ} \mathrm{C}$ ). A 0.2 wt.\% Fe loading (i.e. $\mathrm{Pt} 1.1 \mathrm{Fe} 0.2 / \mathrm{BN}$ ) shows an optimum combination of crotyl alcohol selectivity and conversion resulting in the highest yield.

Fig. 3 shows the conversions of crotonaldehyde hydrogenation and the selectivities of crotyl alcohol, butanol and butyraldehyde on $\mathrm{Pt} 1.1 \mathrm{Fe} 0.2 / \mathrm{BN}$ catalyst in the reaction temperature ranging $40-120{ }^{\circ} \mathrm{C}$. By and large, the selectivities of three products change within a narrow range from 40 to $120{ }^{\circ} \mathrm{C}$. The selectivity of crotyl alcohol increases slightly with increasing temperature up to $100{ }^{\circ} \mathrm{C}$. The conversion and the selectivity of crotyl alcohol increased simultaneously implies that not only the rate of crotonaldehyde hydrogenation is increased but also the hydrogenation of $\mathrm{C}=\mathrm{C}$ is significantly suppressed. On the other hand, the selectivity of butanol decreases to $100{ }^{\circ} \mathrm{C}$ then slightly increases at $120{ }^{\circ} \mathrm{C}$ because high temperature $\left(>100{ }^{\circ} \mathrm{C}\right)$ accelerates the hydrogenation thus increases the final product, butanol.

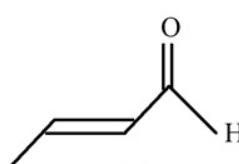

(A)

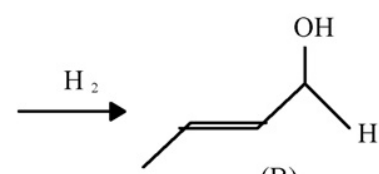

(B)

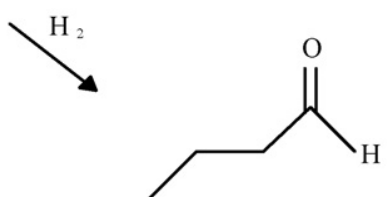

(C)

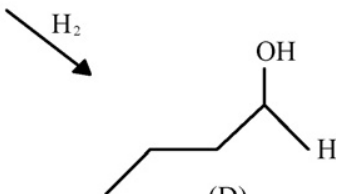

(D)

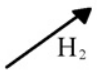

Fig. 1. The hydrogenation path of crotonaldehyde: (A) crotonaldehyde, (B) crotyl alcohol, (C) butyraldehyde, (D) butanol. 


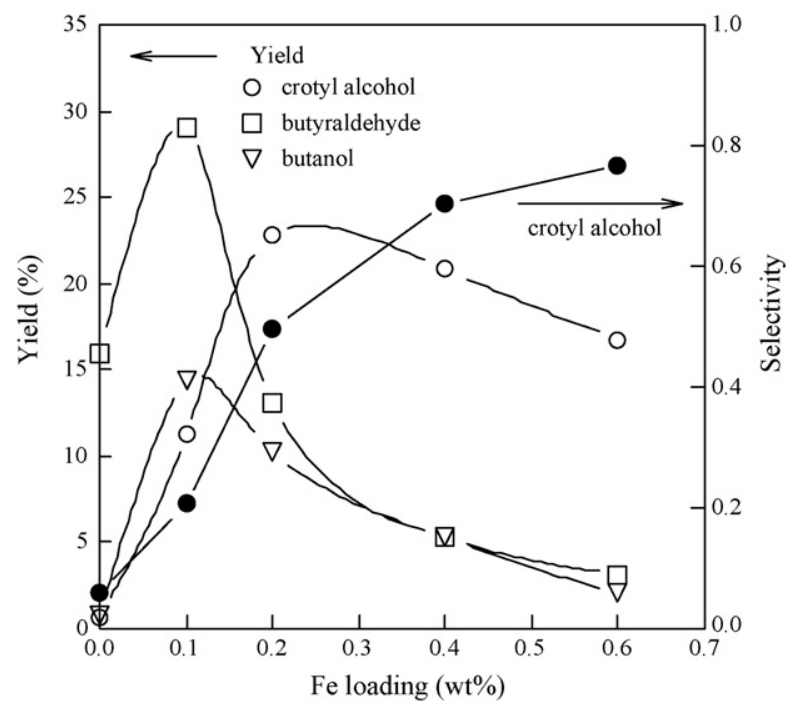

Fig. 2. The effect of Fe loadings on the conversions and selectivities on $\mathrm{PtFe} /$ BN catalysts at $100{ }^{\circ} \mathrm{C}$, feed $50 \mathrm{ml} / \mathrm{min}, \mathrm{H}_{2} /$ crotonaldehyde $=59$.

The influence of $\mathrm{H}_{2}$ partial pressure is shown in Fig. 4. The conversions increase with $\mathrm{H}_{2}$ /crotonaldehyde ratio because of increasing reaction rate by higher $\mathrm{H}_{2}$ pressure. The selectivity of crotyl alcohol only decrease slightly with increasing $\mathrm{H}_{2}$ pressure. Butanol is the final product from further hydrogenation (Fig. 1). Therefore, butanol is favorable under higher $\mathrm{H}_{2}$ pressure and its selectivity increases.

The conversions and product selectivities varied substantially on different catalysts. However, temperature is found to be a weak effect on the product selectivity under our experimental conditions. For a certain catalyst, its product selectivities only slightly change in the temperature range of $40-120{ }^{\circ} \mathrm{C}$. For conciseness, a reaction temperature $100{ }^{\circ} \mathrm{C}$ is selected to represent the performance of all catalysts. Table 2 summarizes the activity, conversion, the crotyl alcohol

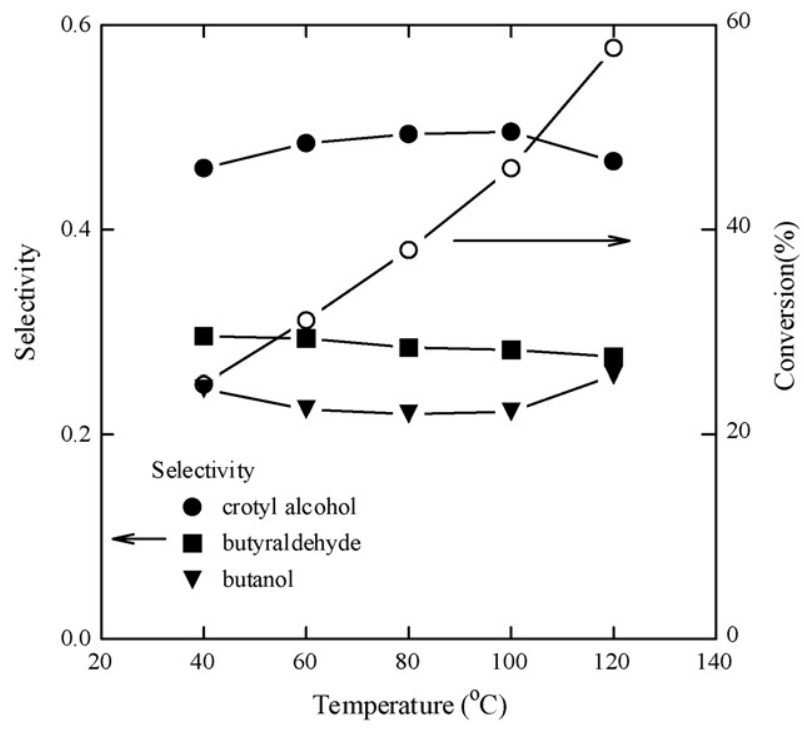

Fig. 3. Conversion of crotonaldehyde and selectivity of products on $\mathrm{Pt} 1.1 \mathrm{Fe} 0.2 /$ $\mathrm{BN}$, feed $50 \mathrm{ml} / \mathrm{min}, \mathrm{H}_{2} /$ crotonaldehyde $=59$.

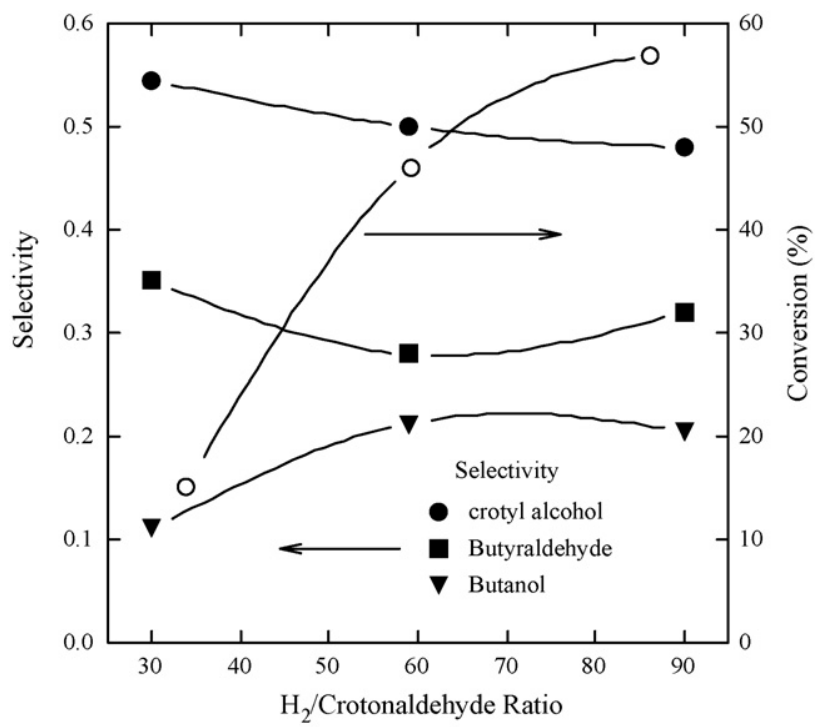

Fig. 4. Effect of $\mathrm{H}_{2}$ /crotonaldehyde ratio on conversion and selectivities in $\mathrm{Pt} 1.1 \mathrm{Fe} 0.2 / \mathrm{BN}$ at reaction temperature $100{ }^{\circ} \mathrm{C}$, feed $50 \mathrm{ml} / \mathrm{min}$.

selectivity and yield for all catalysts at $100{ }^{\circ} \mathrm{C}$. Among the monometallic Pt catalysts, the Pt1.1/BN has the lowest conversion, $17.1 \%$, compared with those of Pt1.1/G and $\mathrm{Pt} 1.1 / \gamma-\mathrm{Al}_{2} \mathrm{O}_{3}$. The low activity of $\mathrm{Pt} / \mathrm{BN}$ is obviously due to its poor Pt dispersion (Table 1). All monometallic catalysts give very low crotyl alcohol selectivity.

Surface $\mathrm{Pt}$ is the major role in the hydrogenation because of its capability of $\mathrm{H}_{2}$ dissociation. $\mathrm{Fe}$ addition suppresses the activity of hydrogenation due to the Fe coverage yet increases the crotyl alcohol selectivity. Although the exposure Pt can be expressed by $\mathrm{H}_{2}$ chemisorption (Table 1), the active site may be underestimated due to the influence of $\mathrm{Fe}$ on PtFe catalysts. In stead of turnover frequency (TOF), the activity is reported based on the Pt loading to show the efficiency of Pt contribution.

The selectivity of crotyl alcohol increases substantially on bimetallic PtFe catalysts under the same reaction conditions.

Table 2

Summary of the crotonaldehyde hydrogenation on all catalysts at $100{ }^{\circ} \mathrm{C}$

\begin{tabular}{lclll}
\hline Catalyst & $\begin{array}{l}\text { Conversion } \\
(\%)\end{array}$ & Selectivity & $\begin{array}{l}\text { Yield } \\
(\%)^{\mathrm{a}}\end{array}$ & $\begin{array}{l}\text { Activity } \\
(\mathrm{mmol} / \mathrm{g}-\mathrm{Pts})\end{array}$ \\
\hline $\mathrm{Pt} 1.1 / \mathrm{BN}$ & 17.1 & 0.04 & 17.1 & 1.93 \\
$\mathrm{Pt} 1.1 \mathrm{Fe} 0.1 / \mathrm{BN}$ & 57.9 & 0.21 & 12.2 & 6.14 \\
$\mathrm{Pt} 1.1 \mathrm{Fe} 0.2 / \mathrm{BN}$ & 46.1 & 0.50 & 23.1 & 5.20 \\
$\mathrm{Pt} 1.1 \mathrm{Fe} 0.4 / \mathrm{BN}$ & 29.5 & 0.71 & 20.9 & 3.33 \\
$\mathrm{Pt} 1.1 \mathrm{Fe} 0.6 / \mathrm{BN}$ & 21.8 & 0.77 & 16.8 & 2.46 \\
$\mathrm{Pt} 1.1 / \mathrm{G}$ & 59.7 & 0.16 & 9.5 & 6.73 \\
$\mathrm{Pt} 1.1 \mathrm{Fe} 0.2 / \mathrm{G}$ & 24.5 & 0.66 & 16.2 & 2.77 \\
$\mathrm{Pt} 1.1 \mathrm{Fe} 0.4 / \mathrm{G}$ & 15.3 & 0.81 & 12.4 & 1.73 \\
$\mathrm{Pt} 1.1 \mathrm{Fe} 0.6 / \mathrm{G}$ & 9.9 & 0.82 & 8.1 & 1.11 \\
$\mathrm{Pt} 1.1 / \gamma-\mathrm{Al}{ }_{2} \mathrm{O}_{3}$ & 66.6 & 0.09 & 6.0 & 4.80 \\
$\mathrm{Pt} 1.1 \mathrm{Fe} 0.2 / \gamma-\mathrm{Al}_{2} \mathrm{O}_{3}$ & 67.9 & 0.08 & 5.4 & 6.41 \\
$\mathrm{Pt} 1.1 \mathrm{Fe} 0.4 / \gamma-\mathrm{Al}_{2} \mathrm{O}_{3}$ & 52.5 & 0.14 & 7.4 & 4.17 \\
$\mathrm{Pt} 1.1 \mathrm{Fe} 0.6 / \gamma-\mathrm{Al}_{2} \mathrm{O}_{3}$ & 32.2 & 0.20 & 6.4 & 2.54 \\
\hline
\end{tabular}

Catalysts $\mathrm{H}_{2}$ reduced at $300{ }^{\circ} \mathrm{C}$ for $2 \mathrm{~h}$, total flow rate is $50 \mathrm{ml} / \mathrm{min}$.

${ }^{\text {a }}$ Yield $=\frac{\text { conversion } \times \text { selectivity }}{100}$.

${ }^{\mathrm{b}} \mathrm{G}$ : graphite. 
Surprisingly, compared with Pt1.1/BN, both conversion (or activity) and selectivity increase simultaneously on $\mathrm{PtFe} / \mathrm{BN}$ series catalysts resulting in the significant crotyl alcohol yield increase. The selectivity of crotyl alcohol increases while the conversion decreases with increasing Fe loadings on PtFe/ $\mathrm{BN}$ series catalysts. The selectivity of crotyl alcohol is improved to 0.77 with $0.6 \mathrm{wt} . \%$ of Fe. The optimum yield of crotyl alcohol achieved $23.1 \%$ with a conversion $46.1 \%$ on $\mathrm{Pt} 1.1 \mathrm{Fe} 0.2 / \mathrm{BN}$.

For graphite-supported catalysts, compared with Pt1.1/G, the conversions of $\mathrm{PtFe} / \mathrm{G}$ series catalysts decrease dramatically while selectivities of crotyl alcohol are greatly enhanced with increasing $\mathrm{Fe}$ loadings. For $\gamma-\mathrm{Al}_{2} \mathrm{O}_{3}$ supported catalysts, the $\mathrm{Fe}$ addition somewhat decreases the conversion and slightly improves the crotyl alcohol selectivity compared with $\mathrm{Pt} 1.1 / \gamma$ $\mathrm{Al}_{2} \mathrm{O}_{3}$. Overall, the yields of crotyl alcohol in $\mathrm{PtFe} / \mathrm{BN}$ series catalysts are much higher than those of $\mathrm{PtFe} / \mathrm{G}$ and $\mathrm{PtFe} / \gamma$ $\mathrm{Al}_{2} \mathrm{O}_{3}$.

\subsection{Characterization of catalysts}

Fig. 5 shows the XRD spectra of BN supported series catalysts with 4 times metal loadings. These catalysts were prepared using the same procedure as those of normal metal loadings, and were $\mathrm{H}_{2}$ reduced at $300{ }^{\circ} \mathrm{C}$. The spectrum of $\mathrm{Fe} 3.2 / \mathrm{BN}$ is the same as that of $\mathrm{BN}$ support. No characteristic peak of Fe can be found. This absence indicates that either individual Fe particles do not exist or are very small in size. The major characteristic peaks of Pt are clearly shown at $39.8^{\circ}$ and $46.2^{\circ}$ in $\mathrm{Pt} 4.4 / \mathrm{BN}$ (i.e. Pt1.1/BN) and $\mathrm{Pt} 4.4 \mathrm{Fe} 0.8 / \mathrm{BN}$ (i.e. $\mathrm{Pt} 1.1 \mathrm{Fe} 0.2 / \mathrm{BN})$. The characteristic peaks of $\mathrm{PtFe}$ alloy are at $40.4^{\circ}$ and $47.0^{\circ}$ and are observed in $\mathrm{Pt} 4.4 \mathrm{Fe} 0.8 / \mathrm{BN}$ (i.e. $\mathrm{Pt} 1.1 \mathrm{Fe} 0.2 / \mathrm{BN}$ ), $\mathrm{Pt} 4.4 \mathrm{Fe} 1.6 / \mathrm{BN}$ (i.e. $\mathrm{Pt} 1.1 \mathrm{Fe} 0.2 / \mathrm{BN}$ ) and Pt4.4Fe2.4/BN (i.e. Pt1.1Fe0.2/BN) [15]. The rest of the characteristic peaks of PtFe alloy are not marked because they

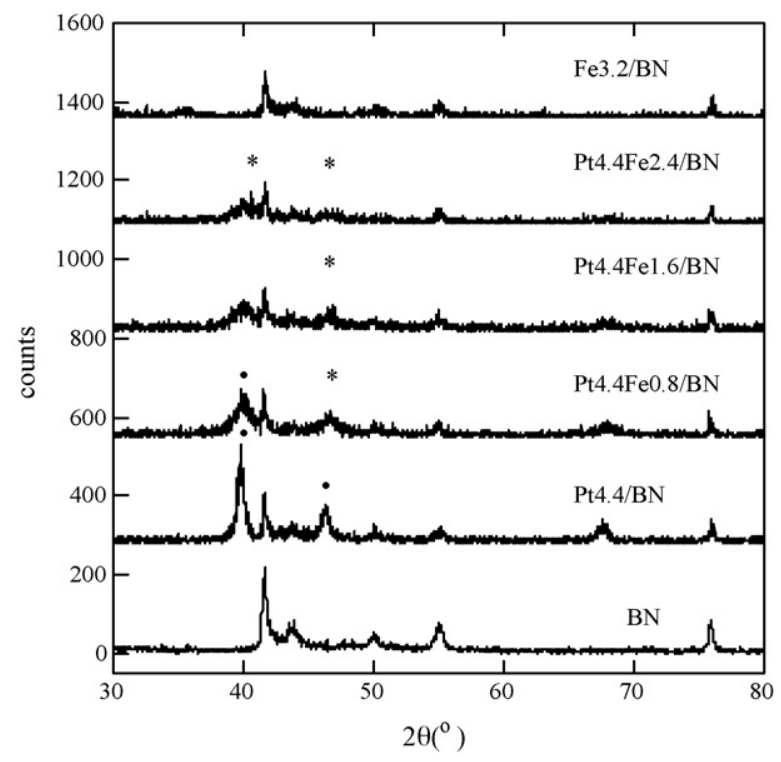

Fig. 5. XRD spectra of $\mathrm{PtFe} / \mathrm{BN}$ catalysts $\mathrm{H}_{2}$ reduced at $300{ }^{\circ} \mathrm{C},(\mathbf{O}) \mathrm{Pt},(*)$ $\mathrm{PtFe}$.

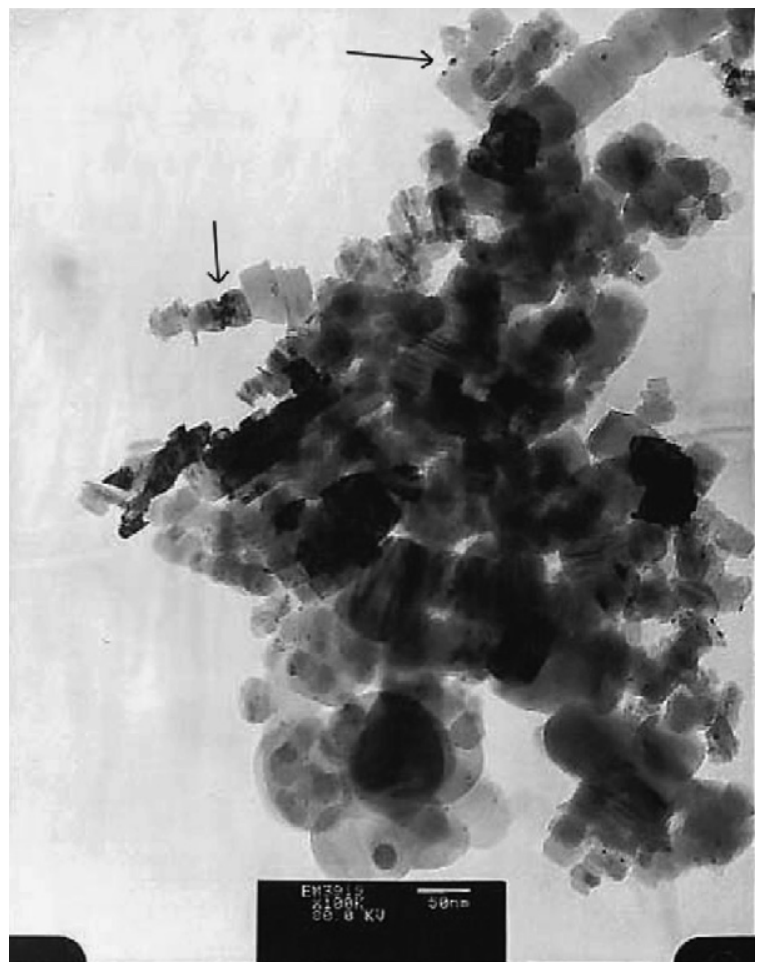

Fig. 6. TEM micrograph of Pt1.1Fe0.2/BN catalyst.

are overlapped with those of $\mathrm{Pt}$ or $\mathrm{BN}$. A small portion of $\mathrm{Pt}$ particles can be found in $\mathrm{Pt} 4.4 \mathrm{Fe} 0.8 / \mathrm{BN}$ (i.e. Pt1.1Fe0.2/BN), as shown in its XRD spectrum. With a higher Fe loading, such as $\mathrm{Pt} 4.4 \mathrm{Fe} 1.6 / \mathrm{BN}$ and $\mathrm{Pt} 4.4 \mathrm{Fe} 2.4 / \mathrm{BN}$, the characteristic peaks of $\mathrm{Pt}$ are diminished, indicating that no individual $\mathrm{Pt}$ particles are present. Therefore, the PtFe alloy is formed during the $\mathrm{H}_{2}$ reduction in $\mathrm{PtFe} / \mathrm{BN}$ series catalysts. The XRD spectra (not shown) of $\mathrm{Pt} / \gamma-\mathrm{Al}_{2} \mathrm{O}_{3}$ and $\mathrm{PtFe} / \gamma-\mathrm{Al}_{2} \mathrm{O}_{3}$ series catalysts reduced at $300{ }^{\circ} \mathrm{C}$ are the same as the background spectra of $\gamma-\mathrm{Al}_{2} \mathrm{O}_{3}$. The metal particles are too small to be observed in the $\mathrm{XRD}$, revealing highly dispersed $\mathrm{Pt}$ and/or PtFe particles on the $\gamma-\mathrm{Al}_{2} \mathrm{O}_{3}$ support. For graphite supported $\mathrm{Pt}$ and $\mathrm{PtFe}$ catalysts, no characteristic peaks can be identified. Thus, the size of metal particles may be similar to those on the $\gamma-\mathrm{Al}_{2} \mathrm{O}_{3}$ support.

Fig. 6 displays the TEM micrograph of Pt1.1Fe0.2/BN. BN support appears flaky and has an irregular shape. Most of metal particles with sizes less than $10 \mathrm{~nm}$ can be observed in the TEM micrograph. Furthermore it can be observed that most of the $\mathrm{Pt}$ or PtFe particles are located on the edges of BN support.

Fig. 7 shows the XPS of the fresh and $\mathrm{H}_{2}$ reduced of Pt4.4Fe0.8/BN (i.e. Pt1.1Fe0.2/BN) catalysts, respectively. The chemical status is identified to be $\mathrm{Fe}^{2+}$ as indicated by its binding energy of $\mathrm{Fe} 2 \mathrm{p}_{3 / 2}$ at $709.3 \mathrm{eV}$ [16]. The $\mathrm{Fe}^{2+}$ is retained even after $\mathrm{H}_{2}$ reduction at $300{ }^{\circ} \mathrm{C}$.

The Pt chemical status of Pt4.4Fe0.8/BN (i.e. Pt1.1Fe0.2/ $\mathrm{BN}$ ) and Pt4.4BN (i.e. Pt1.1/BN) is disclosed in Fig. 8. The binding energy of $\mathrm{Pt} 4 \mathrm{f}_{7 / 2}$ in $\mathrm{Pt} 4.4 / \mathrm{BN}$ is detected at $71.5 \mathrm{eV}$ indicating the metal $\mathrm{Pt}^{\circ}$ after $\mathrm{H}_{2}$ reduction for $2 \mathrm{~h}$ at $300^{\circ} \mathrm{C}$. The Pt $4 \mathrm{f}_{7 / 2}$ of the fresh $\mathrm{Pt} 4.4 \mathrm{Fe} 0.8 / \mathrm{BN}$ is located at $75.7 \mathrm{eV}$ indicating the $\mathrm{Pt}^{4+}$ state [16]. Compared with reduced $\mathrm{Pt} 4.4 /$ $\mathrm{BN}$, the binding energy of $\mathrm{Pt}$ in the $\mathrm{H}_{2}$ reduced $\mathrm{Pt} 4.4 \mathrm{Fe} 0.8 / \mathrm{BN}$ 


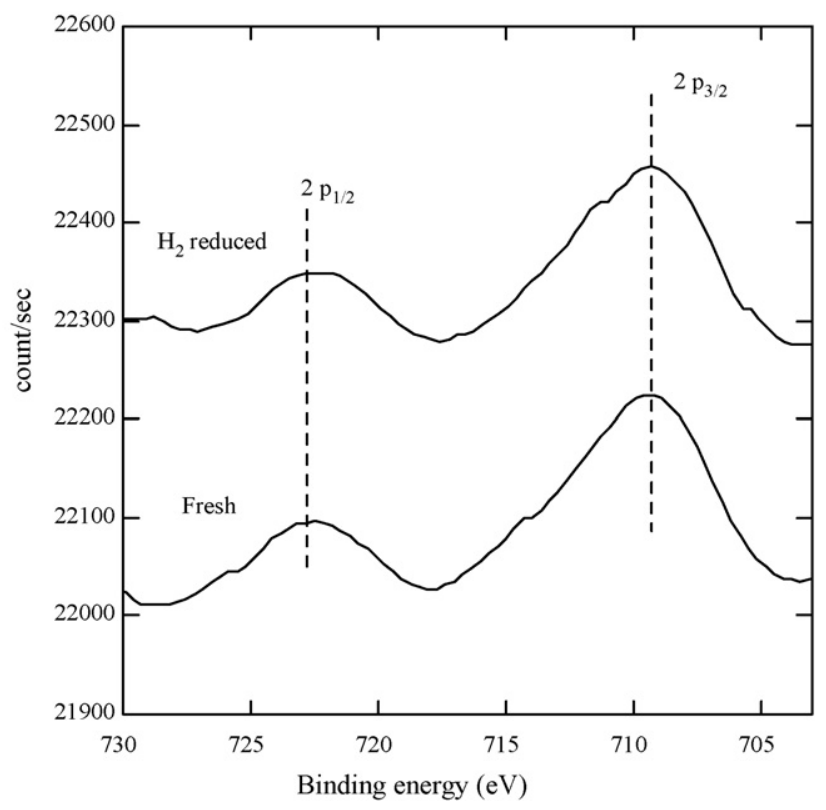

Fig. 7. XPS of $\mathrm{Fe} 2 \mathrm{p}_{3 / 2}$ and $2 \mathrm{p}_{1 / 2}$ on $\mathrm{Pt} 4.4 \mathrm{Fe} 0.8 / \mathrm{BN}$, Fresh and $\mathrm{H}_{2}$ reduced at $300{ }^{\circ} \mathrm{C}$.

shows $0.4 \mathrm{eV}$ positive shift to 71.9 revealing surface Pt may be positively charged due to the surrounding $\mathrm{Fe}^{2+}$ on $\mathrm{PtFe}$ alloy [17]. After $\mathrm{H}_{2}$ reduction, the surface $\mathrm{Pt}$ on $\mathrm{Pt} 4.4 \mathrm{Fe} 0.8 / \mathrm{BN}$ is mostly reduced but $\mathrm{Fe}$ is not reducible (Fig. 7).

The $\mathrm{H}_{2}$ reduction of fresh $\mathrm{PtFe} / \mathrm{BN}$ series catalysts is studied by employing TPR as shown in Fig. 9. The Pt1.1/BN gives lowest reduction temperature at $155^{\circ} \mathrm{C}$. Table 3 summaries the peaks of reduction temperatures on all catalysts on three supports. The reduction temperatures of $\mathrm{Pt} 1.1 / \mathrm{G}$ and $\mathrm{Pt} 1.1 / \gamma$ $\mathrm{Al}_{2} \mathrm{O}_{3}$ are at $184{ }^{\circ} \mathrm{C}$ and $228{ }^{\circ} \mathrm{C}$, respectively. The decomposition and/or reduction of $\mathrm{Pt}$ precursor at lower temperature

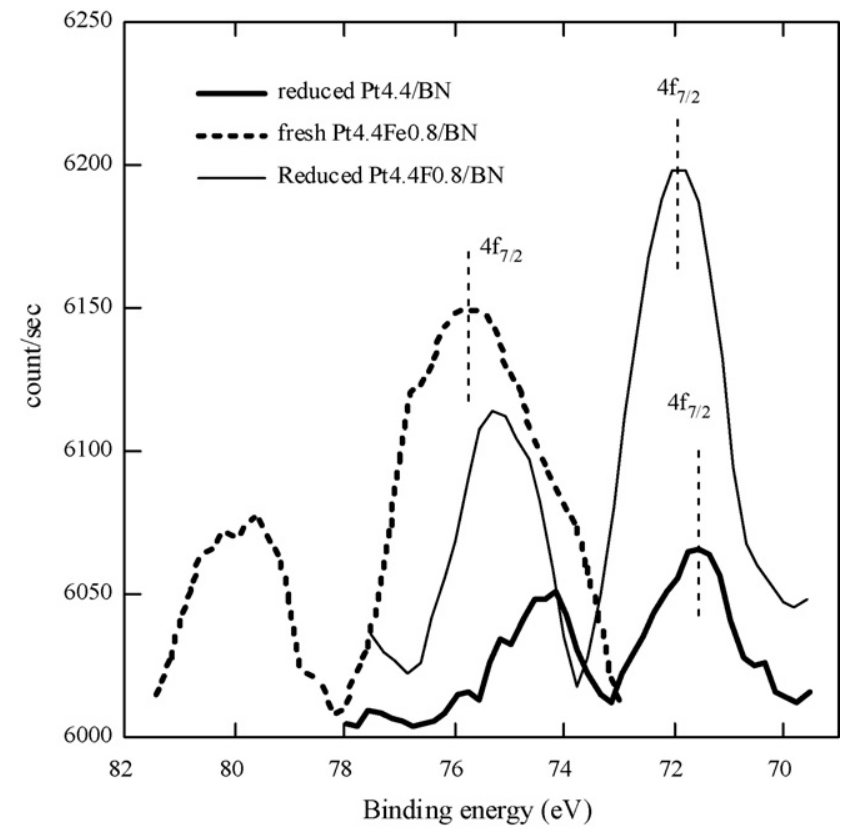

Fig. 8. XPS of Pt $4 \mathrm{f}_{7 / 2}$ and $4 \mathrm{f}_{5 / 2}$ on Pt/BN and Pt4.4Fe0.8/BN catalysts.

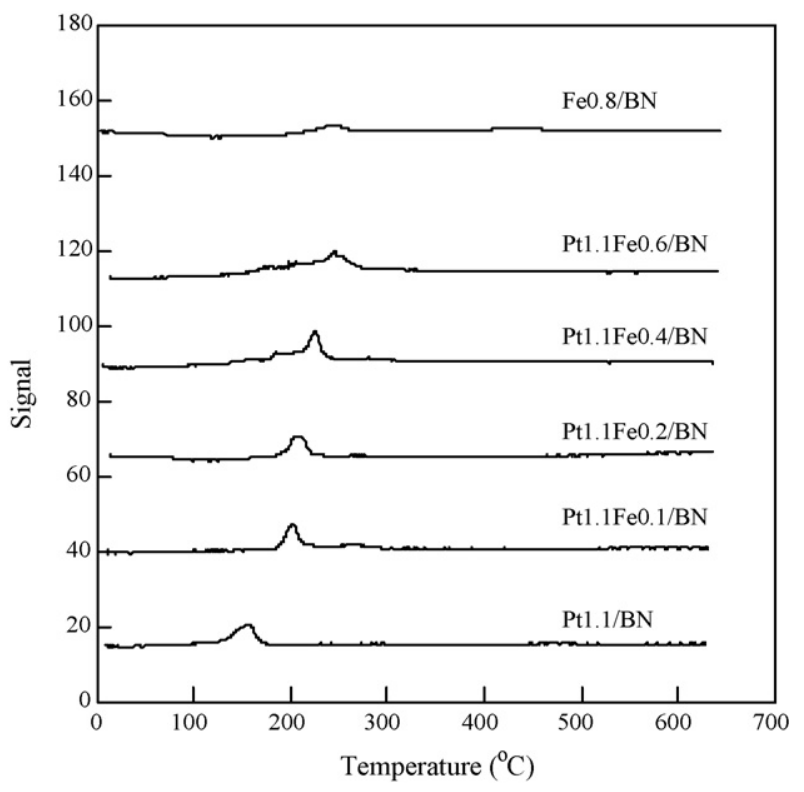

Fig. 9. Temperature programmed reduction of fresh $\mathrm{PtFe} / \mathrm{BN}$ catalysts.

indicates less metal-support interference on $\mathrm{BN}$ than on graphite or $\gamma-\mathrm{Al}_{2} \mathrm{O}_{3}$. The $\mathrm{H}_{2}$ reduction of all $\mathrm{PtFe} / \mathrm{BN}$ series catalysts are in the range of $202-245^{\circ} \mathrm{C}$. The reduction temperature increases with increasing Fe loadings. Similar trend of the reduction temperature $\left(216-247^{\circ} \mathrm{C}\right)$ is also observed on $\mathrm{PtFe} / \mathrm{G}$ series catalysts, but not on $\mathrm{PtFe} / \gamma-\mathrm{Al}_{2} \mathrm{O}_{3}$ series catalysts. All reduction temperatures of $\mathrm{PtFe} / \gamma-\mathrm{Al}_{2} \mathrm{O}_{3}$ series catalysts are near that of $\mathrm{Pt} / \gamma-\mathrm{Al}_{2} \mathrm{O}_{3}$ at $\sim 230{ }^{\circ} \mathrm{C}$ indicating that only $\mathrm{Pt}$ is reduced on $\mathrm{PtFe} / \gamma-\mathrm{Al}_{2} \mathrm{O}_{3}$. Such observable fact implies that $\gamma-\mathrm{Al}_{2} \mathrm{O}_{3}$ may constrain the mobility of $\mathrm{Pt}$ and $\mathrm{Fe}$ during $\mathrm{H}_{2}$ reduction due to the metal-support affinity. It is suspected that no PtFe alloy is formed on $\gamma-\mathrm{Al}_{2} \mathrm{O}_{3}$ support under $300{ }^{\circ} \mathrm{C}$. The tendency to form $\mathrm{PtFe}$ alloy may be the reason resulting in the increase reduction temperature. From the reduction temperatures indicate that the formation of PtFe alloy is much easier on $\mathrm{BN}$ than on $\gamma-\mathrm{Al}_{2} \mathrm{O}_{3}$, and graphite is in between.

Table 3

The $\mathrm{H}_{2}$ reduction temperatures of $\mathrm{Pt}$ and $\mathrm{PtFe}$ on different supports

\begin{tabular}{ll}
\hline Catalyst & $\mathrm{H}_{2}$ reduction temperature $\left({ }^{\circ} \mathrm{C}\right)$ \\
\hline $\mathrm{Pt} 1.1 / \mathrm{BN}$ & 155 \\
$\mathrm{Pt} 1.1 \mathrm{Fe} 0.1 / \mathrm{BN}$ & 202 \\
$\mathrm{Pt} 1.1 \mathrm{Fe} 0.2 / \mathrm{BN}$ & 210 \\
$\mathrm{Pt} 1.1 \mathrm{Fe} 0.4 / \mathrm{BN}$ & 226 \\
$\mathrm{Pt} 1.1 \mathrm{Fe} 0.6 / \mathrm{BN}$ & 245 \\
$\mathrm{Pt} 1.1 / \mathrm{G}^{\mathrm{a}}$ & 184 \\
$\mathrm{Pt} 1.1 \mathrm{Fe} 0.2 / \mathrm{G}$ & 216 \\
$\mathrm{Pt} 1.1 \mathrm{Fe} 0.4 / \mathrm{G}$ & 237 \\
$\mathrm{Pt} 1.1 \mathrm{Fe} 0.6 / \mathrm{G}$ & 247 \\
$\mathrm{Pt} 1.1 / \gamma-\mathrm{Al}_{2} \mathrm{O}_{3}$ & 228 \\
$\mathrm{Pt} 1.1 \mathrm{Fe} 0.2 / \gamma-\mathrm{Al}_{2} \mathrm{O}_{3}$ & 228 \\
$\mathrm{Pt} 1.1 \mathrm{Fe} 0.4 / \gamma-\mathrm{Al}_{2} \mathrm{O}_{3}$ & 227 \\
$\mathrm{Pt} 1.1 \mathrm{Fe} 0.6 / \gamma-\mathrm{Al}_{2} \mathrm{O}_{3}$ & 234 \\
\hline
\end{tabular}

${ }^{a} \mathrm{G}$ : graphite. 


\section{Discussion}

The activity boost of crotonaldehyde hydrogenation and the selectivity enhancement of crotyl alcohol are attributed to the formation of PtFe alloy particles on BN support. Both Pt and $\mathrm{PtFe}$ alloy are formed at low $\mathrm{Fe}$ wt.\%, but only PtFe are found at a higher Fe loadings on BN support (Fig. 5). The enhanced hydrogenation of the $\mathrm{C}=\mathrm{O}$ bond is due to the promoting effect of the oxidized $\mathrm{Fe}^{2+}$ species [7]. The active sites may be in the boundary zone between $\mathrm{Pt}$ and iron oxide on the PtFe alloy particle. Therefore, the high portion of PtFe alloy and surface $\mathrm{Fe}^{2+}$ with moderate levels of metal dispersion in Pt1.1Fe0.2/BN give the highest yield for the selective hydrogenation of the $\mathrm{C}=\mathrm{O}$ bond in crotonaldehyde.

Boron nitride provides an inert and slippery surface that facilitates the formation of $\mathrm{PtFe}$ alloy during $\mathrm{H}_{2}$ reduction due to the unrestrained migration of metal particles. On the other hand, $\gamma-\mathrm{Al}_{2} \mathrm{O}_{3}$ may constrain the mobility of $\mathrm{Pt}$ and $\mathrm{Fe}$ during $\mathrm{H}_{2}$ reduction due to the metal-support affinity, thus preventing the formation of PtFe alloy particles. The size of PtFe alloy particles is also an important factor to be considered because crotonaldehyde hydrogenation is structure-sensitive [18]. Although graphite also provides a similar surface like BN thus the PtFe alloy particles are formed on $\mathrm{PtFe} / \mathrm{G}$, the $\mathrm{PtFe}$ particles may be too small to notably either enhance $\mathrm{C}=\mathrm{O}$ hydrogenation. However, the formation of PtFe alloy particles also reduces the dispersion of $\mathrm{Pt}$ on $\mathrm{BN}$ and graphite, so that the activity of hydrogenation is depressed with increasing $\mathrm{Fe}$ loadings (Table 2).

A PtFe alloy particle with surface $\mathrm{Pt}^{\mathrm{o}}$ and $\mathrm{Fe}^{2+}$ on $\mathrm{BN}$ support is proposed to be the origin to improve the selectivity of crotyl alcohol and the activity in crotonaldehyde hydrogenation. The surface $\mathrm{Fe}^{2+}$ behaves as a Lewis acid site attracting the $\mathrm{C}=\mathrm{O}$ group of a crotonaldehyde molecule. The nearby $\mathrm{Pt}^{\mathrm{o}}$ can supply the absorbed hydrogen to conduct the hydrogenation of the $\mathrm{C}=\mathrm{O}$ bond, instead of the $\mathrm{C}=\mathrm{C}$ bond. The negligible interaction of $\mathrm{BN}$ and the PtFe particle can easily maintain the reduced state of the surface $\mathrm{Pt}^{\mathrm{O}}$, thus causing a weaker adsorbed hydrogen. Such highly active hydrogen facilitates the process of hydrogenation. The partial coverage of $\mathrm{Fe}^{2+}$ on PtFe particles also inhibits the hydrogenation of the $\mathrm{C}=\mathrm{C}$ bond. In addition, partially $\mathrm{Fe}^{2+}$ covered $\mathrm{PtFe}$ alloy particle balances the activity and selectivity of crotyl alcohol thus gives the highest yield.

\section{Conclusions}

This study has presented favorable findings for the selective hydrogenation of $\alpha, \beta$-unsaturated aldehyde into unsaturated alcohol by employing BN supported PtFe catalysts. Although butyraldehyde and butanol in crotonaldehyde hydrogenation are favorable based on thermodynamic equilibrium, the product selectivity is shifted to crotyl alcohol because $\mathrm{C}=\mathrm{O}$ hydrogenation is preferential on the $\mathrm{PtFe}$ alloy particles in $\mathrm{BN}$ support. Boron nitride exhibits an unique property of minimum metal-support interference compared with traditional metal oxides. Therefore, boron nitride offers a promising support for selective hydrogenation catalyst.

\section{Acknowledgement}

The authors would like to thank the National Science Council of the Republic of China, Taiwan for financially supporting this research under Contract No. NSC-94-2214-E-002-029.

\section{References}

[1] P. Gallezot, D. Richard, Catal. Rev. Sci. Eng. 40 (1\&2) (1998) 81.

[2] B.E. Polling, J.M. Prausnitz, J.P. O'Connell, The Properties of Gases and Liquids, fifth ed., McGraw-Hill, New York, 2000, p. 3.15-3.40.

[3] M. Consonni, D. Jokic, D. Yu Murzin, R. Touroude, J. Catal. 188 (1999) 165.

[4] F. Ammari, J. Lamotte, R. Touroude, J. Catal. 221 (2004) 32.

[5] Y. Pei, H. Hu, J. Fang, M. Qiao, W. Dai, K. Fan, H. Li, J. Mol. Catal. A: Chem. 211 (2004) 243.

[6] P. Concepción, A. Corma, J. Silvestre-Albero, V. Franco, J.Y. ChaneChing, J. Am. Chem. Soc. 126 (2004) 5523.

[7] M. Englisch, V.S. Ranade, J.A. Lercher, J. Mol. Catal. A: Chem. 121 (1997) 69.

[8] F. Delbecq, P. Sautet, J. Catal. 164 (1996) 152.

[9] Z.-A. Lin, J.C.S. Wu, J.-W. Pan, C.-T. Yeh, J. Catal. 210 (1) (2002) 39.

[10] J.C.S. Wu, Y.-C. Fan, C.-A. Lin, Ind. Eng. Chem. Res. 42 (14) (2003) 3225.

[11] S. Alkoy, C. Toy, T. Gonul, A. Tekin, J. Eur. Ceram. Soc. 17 (1997) 1415.

[12] J.C.S. Wu, W.-C. Chen, Appl. Catal. A: Gen. 289 (2) (2005) 179.

[13] J.C.-S. Wu, Z.-A. Lin, J.-W. Pan, M.-H. Rei, Appl. Catal. A: Gen. 219 (2001) 117.

[14] C.H. Yang, J.G. Goodwin Jr., J. Catal. 78 (1982) 182.

[15] International centre for diffraction data (JCPDS-ICDD PDF-2 Database version 2.15), Academia Sinica (1987).

[16] J.F. Moulder, W.F. Stickle, P.E. Sobol, K.D. Bombem, Handbook of XRay Photoelectron Spectroscopy, Physical Electronic Inc., Eden Prairie, MN, 1995.

[17] D.I. Jerdev, B.E. Koe, Surf. Sci. 513 (2002) L391.

[18] M. Englisch, A. Jentys, J.A. Lercher, J. Catal. 166 (1997) 25. 